\title{
Analysing popular music: theory, method and practice
}

\author{
by Philip Tagg
}

\section{Important preface}

I wrote this article a long time ago (1981). While I still agree with the gist of that text, my thinking about semiotic music analysis has developed considerably over the intervening decades. ${ }^{1}$

Apart from the inclusion of new footnotes, a few corrected typos, the renumbering of music examples and this short preface, the only significant differences between this document and the original text from 1982 concern terminology. Several concepts used in my doctoral thesis (Tagg, 1979) and in the original article did not turn out to be entirely satisfactory and have been replaced here by more adequate terms. ${ }^{2}$

Music's Meanings (Tagg, 2013) contains all the ideas presented in this old article, in addition to the various improvements of theory and method developed since its original publication. If, out of historical curiosity, you still want to read the 1982 version without its corrections and improved terminology, please see footnote $3 .^{3}$

Philip Tagg, March 2015

This text was first published in Popular Music, 2 (1982), pp. 37-65

N.B. $\{37\}=$ start of page number 37 in the Popular Music article.

\section{$\{37\}$ Popular music analysis - why?}

One of the initial problems for any new field of study is the attitude of incredulity it meets. The serious study of popular music is no exception to this rule. It is often confronted with an attitude of bemused suspicion implying that there is something weird about taking 'fun' seriously or finding 'fun' in 'serious things'. Such attitudes are of interest when discussing the aims and methods of popular music analysis and serve as an appropriate introduction to this article.

In announcing the first International Conference on Popular Music Research, held at

1. For example: [1] 'Musicology and the Semiotics of Popular Music' 辰 Semiotica, 66-1/3: 279-298 (1987); [2] 'An Anthropology of Television Music?' 无 Svensk tidskrift för musikforskning, 1989: 19-42 (1990); [3] 'Towards a sign typology of music' 尽 Secondo convegno europeo di analisi musicale (ed. R Dalmonte; M Baroni): 369-378. Trento: Università degli studi (1992)'; [4] 'From refrain to rave: the decline of figure and the rise of ground' 言 Popular Music, 13/2: 209-222 (1994); [5] 'The Göteborg connection: lessons in the history and politics of popu-

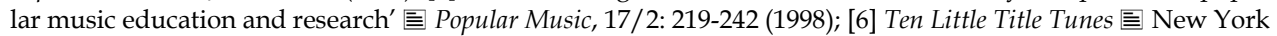
\& Montréal: Mass Media Music Scholars' Press (Tagg \& Clarida, 2003); [7] 'Gestural interconversion and connotative precision' 亞 Film International, 13: 26-40 (2005); [8] 言 Music's Meanings. New York: Mass Media Music Scholars' Press. Many essential aspects of this work since 1982 are presented in Music's Meanings ([ tagg.org/mmmsp/NonMusolnfo.htm).

2. The main terminological changes are: [1] extramusical is almost always replaced by paramusical (Why? See p. 229 in Music's Meanings (Tagg, 2013); [2] the rather vague notion of association is replaced by the more precise term connotation (see Music's Meanings, pp. 161-166); [3] hypothetical substitution is replaced by commutation (shorter and more precise); [4] semiology is replaced by semiotics (see Music's Meanings, pp. 159-160); [5] refrain, not chorus, is used to denote a type of chorus episode whose words and tune change very little, if at all, each time it occurs in a song (Music's Meanings, p. 395); [6] [Western] art music, [European] classical music, etc. are referred to as euroclassical music.

3. The original, unrevised 1982 version of this text is available, for historical comparison purposes, at $\mathbf{\square}$ tagg.org/ articles/xpdfs/pm2analOrig.pdf. It can also be read as hard copy in Popular Music, 2, pp. 37-65. 
Amsterdam in June 1981, The Times Diary printed the headline 'Going Dutch - The Donnish Disciples of Pop' (The Times 16 June 1981). Judging from the generous use of inverted commas, sics and 'would-you-believe-it' turns of phrase, the Times diarist was comically baffled by the idea of people getting together for some serious discussions about a phenomenon which the average Westerner's brain probably spends around twenty-five per cent of its lifetime registering, monitoring and decoding. It should be added that The Times is just as incredulous about " A Yearbook of Popular Music" (sic)' (their sic), in which this 'serious' article about 'fun' now appears.

In announcing the same conference on popular music research, the New Musical Express (20 June 1981, p. 63) was so witty and snappy that the excerpt can be quoted in full.

Meanwhile, over in Amsterdam this weekend, high foreheads from the four corners of the earth (Sid and Doris Bonkers) will meet for the first International Conference on Popular Music at the University of Amsterdam. In between the cheese and wine parties, serious young men and women with goatee beards and glasses will discuss such vitally important issues as 'God, Morality and Meaning in the Recent Songs of Bob Dylan'.4 Should be a barrel of laughs...

This imaginative piece of poetry is itself a great barrel of laughs to anyone present at the conference with its zero ( 0 per cent) wine and cheese parties, one ( 0.8 per cent) goatee beard and a dozen $\{38\}$ (10 per cent) bespectacled participants. (As 'Sid Bonkers', I do admit to having worn contact lenses). Talks were given by active rock musicians, by an ex-NME and Rolling Stone journalist, by radio people and by Paul Oliver, who may have worn glasses but who, even if maliciously imagined with a goatee beard, horns and a trident, has probably done more to increase respect, understanding and enthusiasm for the music of black Americans than the NME is ever likely to.

This convergence of opinion between such unlikely bedfellows as The Times and the $N M E$ about the imagined incongruity of popular music as an area for serious study implies one of two things. Either popular music is so worthless that it should not be taken seriously (unlikely, since pop journalists obviously rely on the existence of popular music for their livelihood) or academics are so hopeless - absent-mindedly mumbling long Latin words under their mortarboards in ivory towers - that the prospect of them trying to deal with anything as important as popular music is just as absurd. However, The Times and NME are not alone in questioning the ability of traditional scholarship to deal with popular music. Here they join forces with no mean number of intellectual musicians and musically interested academics.

Bearing in mind the ubiquity of music in industrialised capitalist society, its importance at both national and transnational levels (see Varis 1975, Chapple and Garofalo 1977, Frith 1978, Fonogrammen i kulturpolitiken 1979) and the share of popular music in all this, the incredible thing is not that academics should start taking the subject seriously but that they have taken such a time getting round to it. Until recently, publicly funded musicology has passively ignored the sociocultural challenge of trying to inform the record-buying, Muzak-registering, TV watching and video-consuming public 'why and how who' (from the private sector) 'is communicating what to whom' (in the public sector) 'and with what effect' (apologies to C S Peirce). Even now it does very little.

Nevertheless, to view the academic world as being full of static and eternal ivory tower stereotypes is to reveal an ahistorical and strangely defeatist acceptance of the schizophrenic status quo in capitalist society. It implies atomisation, compartmentalisation and polarisation of the affective and the cognitive, of private and public, individual and collective, implicit and explicit, entertaining and worrying, fun and serious, etc. The

4. No such talk was on the conference programme! Actually it is the title of Wilfrid Mellers's article in Popular Music 1 (1981, pp. 143-157). 
'never-the-twain-shall-meet' syndrome is totally untenable in the field of popular music (or the arts in general). You don't have to be a don to understand that there are objective developments in nineteenth- and twentieth-century music history which demand that changes be made, not leas in academic circles.

\{39\} These developments can be summarised as follows: (1) a vast increase in the share music takes in the money and time budgets of citizens in the industrialised world; (2) shifts in class structure leading to the advent of socioculturally definable groups, such as young people in student or unemployment limbo between childhood and adulthood, and their need for collective identity; (3) technological advances leading to the development of recording techniques capable (for the first time in history) of accurately storing and allowing for mass distribution of non-written musics; (3) transistorisation, microelectronics and all that such advances mean to the mass dissemination of music; (5) the development of new musical functions in the audiovisual media (for example, films, TV, video, advertising); (6) the 'non-communication' crisis in modern Western art music and the stagnation of official art music in historical moulds; (7) the development of a loud, permanent, mechanical lo-fi soundscape (Schafer 1974, 1977) and its 'reflection' (Riethmüller 1976) in electrified music with regular pulse (Bradley 1980); (8) the general acceptance of certain Euro- and Afro-American genres as constituting a lingua franca of musical expression in a large number of contexts within industrialised society; (9) the gradual, historically inevitable replacement of intellectuals schooled solely in the euroclassical tradition by others exposed to the same tradition but at the same time brought up on Presley, the Beatles and the Stones.

To those of us who during the fifties and sixties played both Scarlatti and soul, did palaeography and Palestrina crosswords as well as working in steelworks, and who walked across quads on our way to the 'Palais' or the pop club, the serious study of popular music is not a matter of intellectuals turning hip or of mods and rockers going academic. It is a question of (a) getting together two equally important parts of experience, the intellectual and emotional, inside our own heads and (b) being able as music teachers to face pupils whose musical outlook has been crippled by those who present 'serious music' as if it could never be 'fun' and 'fun music' as though it could never have any serious implications.

It's in this light that the serious study of popular music becomes obvious, while the case for making it a laughing matter, although understandable (it can be hilarious at times), is basically reactionary and will be dispensed with for the rest of this article. This is because the aim of what follows is to present a musicological model for tackling problems of popular music content analysis. It is hoped that this might be of some use to music teachers, musicians and others looking for a contribution towards the understanding of 'why and how does who communicate what to whom and with what effect'. $\{40\}$

\section{Musicology and popular music research}

Studying popular music is an interdisciplinary matter. Musicology still lags behind other disciplines in the field, especially sociology. The musicologist is thus at a simultaneous disadvantage and advantage. The advantage is that he/she can draw on sociological research to give the analysis proper perspective. Indeed, it should be stated at the outset that no analysis of musical discourse can be considered complete without consideration of social, psychological, visual, gestural, ritual, technical, historical, economic and linguistic aspects relevant to the genre, function, style, (re-)performance situation and listening attitude connected with the sound event being studied. The disadvantage is that musicological 'content analysis' in the field of popular music is still an underdeveloped area and something of a missing link (see Schuler 1978). 


\section{Music analysis and the communication process}

Let us assume music to be that form of interhuman communication in which individually experienceable affective states and processes are conceived and transmitted as humanly organised nonverbal sound structures to those capable of decoding their message in the form of adequate affective and associative response (Tagg 1981b). Let us also assume that music, as can be seen in its modes of 'performance' and reception, most frequently requires by its very nature a group of individuals to communicate either among themselves or with another group; thus most music (and dance) has an intrinsically collective character not shared by the visual and verbal arts. This should mean that music is capable of transmitting the affective identities, attitudes and behavioural patterns of socially definable groups, a phenomenon observed in studies of subcultures and use by US-American format radio to determine advertising markets (Karshner 1971).

Now, although we have considerable insight into socioeconomic, subcultural and psychosocial mechanisms influencing the 'emitter' (by means of biographies, etc.) and 'receiver' of certain types of popular music, we have very little explicit information about the 'channel', about 'the music itself'. We know very little about its 'signifiers' and 'signifieds', about the relations the music establishes between emitter and receiver, about how a musical message actually relates to the set of affective and connotative concepts presumably shared by emitter and receiver, and how it interacts with their respective cultural, social and natural environments. In other words, reverting to the question 'why and how does who say what to whom and with what effect?', we could $\{41\}$ say that sociology answers the questions 'who', 'to whom' and, with some help from psychology, 'with what effect' and possibly parts of 'why', but when it comes to the rest of 'why', not to mention the questions 'what' and 'how', we are left in the lurch, unless musicologists are prepared to tackle the problem (Wedin 1972: 128).

\section{Popular music, notation and musical formalism}

There is no room here to define 'popular music' but to clarify the argument I shall posit an axiomatic triangle consisting of 'folk', 'art' and 'popular' musics. Each of these three is distinguishable from the other two according to the criteria presented in Figure 1 (p. 5). The argument is that popular music cannot be analysed using only the traditional tools of musicology because popular music, unlike conservative notions of euroclassical music, is (1) conceived for mass distribution to large and often socioculturally heterogeneous groups of listeners, (2) stored and distributed in non-written form, (3) only possible in an industrial monetary economy where it becomes a commodity and (4) in capitalist society, subject to the laws of 'free' enterprise, according to which it should ideally sell as much as possible of as little as possible to as many as possible. Consideration of these three distinguishing marks implies that it is impossible to 'evaluate' popular music along some sort of Platonic ideal scale of aesthetic values and, more prosaïcally, that notation should not be the analyst's main source material,. The reason for this is that while notation may be a viable starting point for much art music analysis, in that it was the only form of storage of over a millennium, popular music, not least in its Afro-American guises, is neither conceived nor designed to be stored or distributed as notation, a large number of important parameters of musical expression being either difficult or impossible to encode in traditional notation (Tagg 1979: 28-31). This is, however, not the only problem.

Allowing for certain exceptions, traditional music analysis can be characterised as formalist. One of its great difficulties, criticised by Rösing (1977) in connection with the analysis of euroclassical music, is relating musical discourse to the remainder of human existence in any way, the description of emotive aspects in music either occurring spo- 
radically or being avoided altogether. Perhaps these difficulties are in part attributable to such factors as (1) a kind of exclusivist guild mentality amongst musicians resulting in the ability and/or lack of will to link items of musical expression with phenomena that are not primarily musical; (2) a time-honoured adherence to notation as the only viable form of storing music; (3) a culture-centric fixation on certain notatable parameters of musical expression (mostly $\{42\}$ processual aspects such as episodic 'form', thematic construction, etc.), which are particularly important to the euroclassical tradition. This set of attitudes also includes a nonchalance towards parameters not easily expressed in traditional notation (mostly 'immediate' aspects such as timbre, electromusical sound treatment, etc.), which are relatively unimportant - or ignored - in the analysis of euroclassical music but highly important in popular music (Rösing 1981).

Fig. 1 Folk, art and popular music: an axiomatic triangle.

\begin{tabular}{|c|c|c|c|c|}
\hline \multicolumn{2}{|c|}{ CHARACTERISTIC } & Folk & Art & Popular \\
\hline $\begin{array}{l}\text { Produced and } \\
\text { transmitted by }\end{array}$ & $\begin{array}{c}\text { primarily professionals } \\
\text { primarily amateurs }\end{array}$ & $x$ & $x$ & $x$ \\
\hline $\begin{array}{l}\text { Mass } \\
\text { distribution }\end{array}$ & $\begin{array}{c}\text { usual } \\
\text { unusual }\end{array}$ & $x$ & $x$ & $x$ \\
\hline $\begin{array}{l}\text { Main mode of storage } \\
\text { and distribution }\end{array}$ & $\begin{array}{l}\text { oral transmission } \\
\text { musical notation } \\
\text { recorded sound }\end{array}$ & $x$ & $\mathrm{x}$ & $\mathrm{x}$ \\
\hline $\begin{array}{l}\text { Type of society in which } \\
\text { the category of music } \\
\text { mostly occurs }\end{array}$ & $\begin{array}{l}\text { nomadic or agrarian } \\
\text { agrarian or industrial } \\
\text { industrial }\end{array}$ & $x$ & $x$ & $\mathrm{x}$ \\
\hline $\begin{array}{l}\text { Written theory } \\
\text { and aesthetics }\end{array}$ & $\begin{array}{l}\text { uncommon } \\
\text { common }\end{array}$ & $\begin{array}{l}x \\
x\end{array}$ & $x$ & $x$ \\
\hline $\begin{array}{l}\text { Composer / } \\
\text { Author }\end{array}$ & $\begin{array}{c}\text { anonymous } \\
\text { non-anonymous }\end{array}$ & $x$ & $x$ & $x$ \\
\hline
\end{tabular}

\section{Affect theory and hermeneutics}

Despite the dominance of the formalist tradition in university departments of musicology, the sort of non-referential thinking just described should be seen as a parenthesis in the history of verbal discourse on music, because it is bordered on one side by the Baroque Theory of Affects and on the other by the hermeneutics of music (Zoltai 1970: 137-215). The doctrinal straitjacket of Affect Theory, a sort of combination of feudal absolutism and rationalist curiosity, and its apparent tendency to regard itself as universally applicable (Lang 1942: 438; Zoltai 1970: 177), render it unsuitable for use in popular music analysis which must deal with a multitude of 'languages', ranging from film music in the late romantic symphonic style to punk and from middle-of-the-road pop to the $\{43\}$ Webernesque sonorities of murder music in TV thrillers.

Musical hermeneutics, as a subjectivist approach, is often violently and sometimes justifiably criticised. Indeed, from time to time it can degenerate into exegetic guesswork and 'reading between the lines' (e.g. Cohn, 1970: 54-55; Melzer, 1970: 104, 153; Mellers, 1973: 117-118). Still, hermeneutics can, if used with care and together with other musicological approaches, make an important contribution to the analysis of popular music, not least because it treats music as a symbolic system and encourages synaesthetic thinking on the part of the analyst, a prerequisite for positing verbalisable hypotheses and a necessary step in escaping from the prison of sterile formalism. 
The semiotics and sociology of music

The transfer of structuralist and semiotic methods, derived from linguistics, to the realm of music seemed initially highly promising (see Bernstein 1976). However, several musicologists of semiotic bent (for example Francès 1972, Lerdahl and Jackendoff 1977, Keiler 1978 and Stoïanova 1978), have pointed out that models constructed to explain the denotative aspects of verbal language cannot be transplanted wholesale into the field of music with its connotative, associative-affective character of discourse (see Shepherd 1977). Unfortunately, a great deal of linguistic formalism has crept into the music semiotics, the extrageneric question of relationships between musical signifier and signified and between the musical object under analysis and society being regarded as suspect (Nattiez 1974: 67), or as subordinate to congeneric relationships within the musical object (Nattiez 1974: $72-73$ and 1975: 414-416).

The empirical sociology of music, apart from having acted as a sorely needed alarm, rousing musicologists from their culture-centric and ethnocentric slumbers, and notifying them of musical habits amongst the population at large, can also provide valuable information about $\{44\}$ the functions, uses and (with the help of psychology) the effects of the genre, performance or musical object under analysis. In this way, results from perceptual investigation and other data about musical habits can be used for crosschecking analytical hypotheses and for putting the whole analysis in its sociological and psychological perspectives.

It is clear that a holistic approach to the analysis of popular music is the only viable one if the goal is to reach a full understanding of all factors interacting with the conception, transmission and reception of the object of study. Now although such an approach obviously requires multidisciplinary knowledge on a scale no individual researcher can ever hope to embrace, there are nevertheless degrees of inter- and intradisciplinary outlook, not to mention the possibilities afforded by interdisciplinary teamwork. An interesting approach in this context is that of Assafiev's Intonation Theory (Asafyev 1976), which embraces all levels of musical expression and perception, from onomatopoeic signals to complex formal structures, without placing them on either overt or covert scales of aesthetic value judgement. Intonation theory also tries to put musical analysis into historical, cultural, social and psychological perspective and seems to be a viable alternative to both congeneric formalism and unbridled hermeneutic exegesis, at least as practised in the realm of art music by Asafyev himself (1976: $51 \mathrm{ff}$.) and, in connection with folk music, by Maróthy (1974). Intonation theory has also been applied to the study of popular music by Mühe (1968) and Zak (1979). However, the terminology of intonation theory seems to lack stringency, intonation itself being given a diversity of new meanings by Asafyev himself in addition to those it already possesses (Ling 1978a). It seems wise to adopt the generally holistic and dynamically non-idealist approach of intonation theory in popular music analysis, less wise to adopt its terminology, at least in the West where it is still little known.

There are also several other important publications within non-formalist musicology which combine semiotic, sociological, psychological and hermeneutic approaches, thereby offering ideas which might be useful in the analysis of popular music. Apart from pioneer work carried out in prewar Germany (see Rösing 1981) and by Francès (1972), I should mention in this context publications by Karbušicky (1973), Rösing (1977), Ling (1978b) and Tarasti (1978). However, in none of these publications are the analytical models applied to popular music; this still remains an extremely difficult area, as Rösing (1981) points out in his critique of several West German attempts at tackling the problem. The difficulties are also clearly epitomised by the surprising dearth of analytical methods developed in the anglophone world. $\{45\}$ 
In an interesting analysis of a fourteen-minute LP track by an East German rock group, Wicke (1978) puts forward convincing arguments for treating popular music with new, non-formalist analytical methods. Wicke's analysis poses questions arising from an approach similar to that used here. Therefore, in an effort to find some epistemological gaps I shall proceed to attempt the establishment of a theoretical basis for popular music analysis.

\section{An analytical model for popular music}

The conceptual and methodological tools for popular music analysis presented here are based on some results of current research (Tagg 1979, 1980, 1981a, b). The most important parts of this analytical model are (1) a checklist of parameters of musical expression, (2) the identification of musemes as minimal units of expression and or their compounds (stacks and strings) by means of interobjective comparison, (3) the establishment of figure/ground (melody/accompaniment) relationships, (4) the transformational analysis of melodic phrases, (5) the establishment of patterns of paramusical process, and (6) the falsification of conclusions by means of commutation (hypothetical substitution). These points will be explained and some of them exemplified in the rest of this article. I shall draw examples mainly from my work on the title theme for the TV series Kojak (Tagg 1979) and on Abba's hit recording Fernando (Tagg 1981a).

First, however, this analytical process needs to be put into the context of a scientific paradigm. The discussion that follows should be read in conjunction with figure 2 on page 8. A reading down the centre of this diagram, following the bold lines, traces the process of analysis. Down the sides, joined by thinner lines, are factors that feed into the process of production of the music and which, at the level of ideology, must also be taken into account. First, however, let us concentrate on the hermeneutic/semiotic level, reading down Figure 2 (page 8) as far as 'verbalisation'.

\section{Methodological paradigm for popular music analysis}

It should first be clear that popular music is regarded as a sociocultural field of study (SCFS at top and bottom of Fig. 2). It should also be clear from Figure 2 (p. 8) that there is an access problem involving the selection of analysis object (hereinafter ' $\mathrm{AO}$ ') and analytical method. Choice of study object and method are determined by the researcher's 'mentality', i.e. by his/her world view, ideology, values, objective possibilities, etc., influenced in their turn by the researcher's and the discipline's objective position in a cultural, historical and social $\{46\}$ context. From the previous discussion it should be clear that the analysis of popular music is regarded here as an important contribution to musicology and to cultural studies in general.

[Figure 2, p. 8, was placed here in the 1982 version]

$\{47\}$ The choice of AO is determined to a large extent by practical methodological considerations. At the present stage of enquiry this means two things. Firstly, it seems wise to select an AO which is conceived for and received by large, socioculturally heterogeneous groups of listeners rather than music used by more exclusive, homogeneous groups, simply because it is more logical to study what is generally communicable as a 'rule' before trying to understand particularities or 'exceptions to the rule'. Secondly, since, as we have seen, congeneric formalism has ruled the musicological roost for some time and since the development of more holistic types of analysis is a difficult matter demanding considerable caution, it is best that AOs with relatively clear paramusical fields of connotation (hereinafter 'PMFC') be singled out at this stage. 
Fig. 2. Methodological paradigm for the analysis of popular music. 5



$\mathrm{AO}=$ analysis object

IOCM = interobjective comparison material

IMC $=$ item of musical code

PMFC =paramusical fields of connotation

PMP = patterns of musical process

PPMP = patterns of paramusical process

SCFS = sociocultural field of study

music $_{\mathrm{V}}=$ music as conception (voos $=$ thought, purpose, mind)

music $_{\mathrm{Y}}=$ music as notation $(\gamma \rho \alpha \phi \omega=$ write $)$

5. Thanks to Sven Andersson, Institute for the Theory of Science, University of Göteborg, for help in constructing this model. 
The final choice to be made before actual analysis begins is which stage(s) in the musical communication process to study. Reasons for discarding music as notation $\left(\right.$ music $_{\mathrm{Y}}$ ) have already been presented. Music as perceived by listeners ( music $_{\varphi}$ ) and as conceived by the composer and/or musician before actual performance (music ${ }_{\mathrm{v}}$ ) are on the other hand both highly relevant to the study of popular music, since their relations to each other, to the sounding object (music $\mathrm{v}_{\mathrm{v}}$ ) and to the general sociocultural field of study are all vital parts of the perspective into which any conclusions from the analysis of other stages in the musical communication process must be placed. Nevertheless, however important these aspects may be - and they are vital - , they can only be mentioned in passing here, being referred to the 'ideological' part of the paradigm which follows the hermeneutic-semiotic stage.

Thus, choosing the sounding object (music ${ }_{\mathrm{v}}$ ) as our starting point, we can now discuss actual analytical method.

\section{Hermeneutic-semiotic method}

The first methodological tool is a checklist of parameters of musical expression. Having discussed general aspects of the communication process and any forms of paramusical expression connected with the $\mathrm{AO}, 6$ it is a good idea to make some sort of transcription of the music $_{\mathrm{v}}$, taking into consideration a multitude of musical factors. In drastically abridged form (from Tagg 1979: 68-70), the checklist includes:

1. Aspects of time: duration of $\mathrm{AO}$ and relation of this to any other simultaneous forms of communication; duration of sections within the AO; pulse, tempo, metre, periodicity; rhythmic texture and motifs.

2. Melodic aspects: register; pitch range; rhythmic motifs; tonaity, contour; timbre. $\{48\}$

3. Orchestrational aspects: type and number of voices, instruments, parts; technical aspects of performance; timbre; phrasing; accentuation.

4. Aspects of tonality and texture: tonal centre and type of tonality (if any); harmonic idiom; harmonic rhythm; type of harmonic change; chordal alteration; relationships between voices, parts, instruments; compositional texture and method.

5. Dynamic aspects: levels of sound strength; accentuation; audibility of parts.

6. Acoustical aspects: characteristics of (re-)performance 'venue'; reverberation; distance between sound source and listener; simultaneous 'extraneous' sound.

7. Electromusical and mechanical aspects: panning, filtering, compressing, phasing, distortion, delay, mixing, etc; muting, pizzicato, tongue flutter, etc. (see 3, above).

This list does not need to be applied slavishly. It's just a way of checking that no important parameter of musical expression is overlooked and it can be of help in determining the processual structure of the AO. The reason is that some parameters will be absent, while others will be either constant during the complete $\mathrm{AO}$ (if they are constant during other pieces as well, such a set of AOs will probably constitute a style - see Fabbri 1982) or they will be variable, thus constituting both the immediate and processual interest of the AO, not only as a piece in itself but also in relation to other music. The checklist can also contribute to an accurate description of musemes. These are minimal units of expression in any given musical style (not the same definition as in Seeger 1977) and can be established by the analytical procedure of interobjective comparison.

The inherently alogogenic character of musical discourse is the main reason for using interobjective comparison. The musicologist's eternal dilemma is the need to use words about a nonverbal, non-denotative symbolic system. This apparent difficulty can be turned into an advantage if at this stage of the analysis one discards words as a metalanguage for music and replaces them with other music. This means using the reverse

6. Paramusical (not 'extramusical'): see footnote 2 (p. 1) and Music's Meanings (Tagg, 2013: 229). 
side of a phrase coined in a poem by Göran Sonnevi (1975): 'music cannot be explained away - it can't even be contradicted except by completely new music' ${ }^{7}\{49\}$ Put simply, interobjective comparison means describing music by means of other music; it means comparing the $\mathrm{AO}$ with other music in a relevant style and with similar functions. It works in the following way.

If an analytical approach establishing consistency of response to the same AO (analysis object) is played to a number of respondents is called intersubjective, then an interobjective approach is one that establishes similarities in musical structure between the $\mathrm{AO}$ and other music. Establishing similarities between an $\mathrm{AO}$ and other 'pieces of music' can done by individual analysts on their own, referring to the 'checklist'. The scope of the interobjective comparison material (=IOCM) can, however, be widened considerably by asking other people to do the same. This process establishes a bank of IOCM which, to give some examples, can amount to around 350 pieces in the case of the Kojak title theme and about 130 in relation to Abba's Fernando.

The next step is to search the IOCM for musical elements (items of musical code: IMC) similar to those found in the AO. These elements are often extremely short (musemes), or else consist of general sonorities or of overall expressional constants. Particular musemes, 'motifs' and general sonorities in both the AO and the IOCM which correspond must then be related to paramusical forms of expression. Such relationships can be established if pieces in the IOCM share any common denominators of paramusical connotation in the form of visual or verbal meaning. If they do, then the objective correspondences established between the items of musical code in the analysis object (AO/IMC) and those in the IOCM (IOCM/IMC), and between the musical code of the IOCM (IOCM/IMC) and its paramusical fields of connotation (IOCM/PMFC), lead to the conclusion that there is a demonstrable state of correspondence between the items of musical code in the analysis object (AO/IMC) and the paramusical fields of connotation connected to the interobjective comparison material (IOCM/PMFC) - also of course, between IOCM/IMC and AO/PMFC (see Fig. 3).

Fig. 3. Hermeneutic correspondence by means of interobjective comparison $\{50\}$.

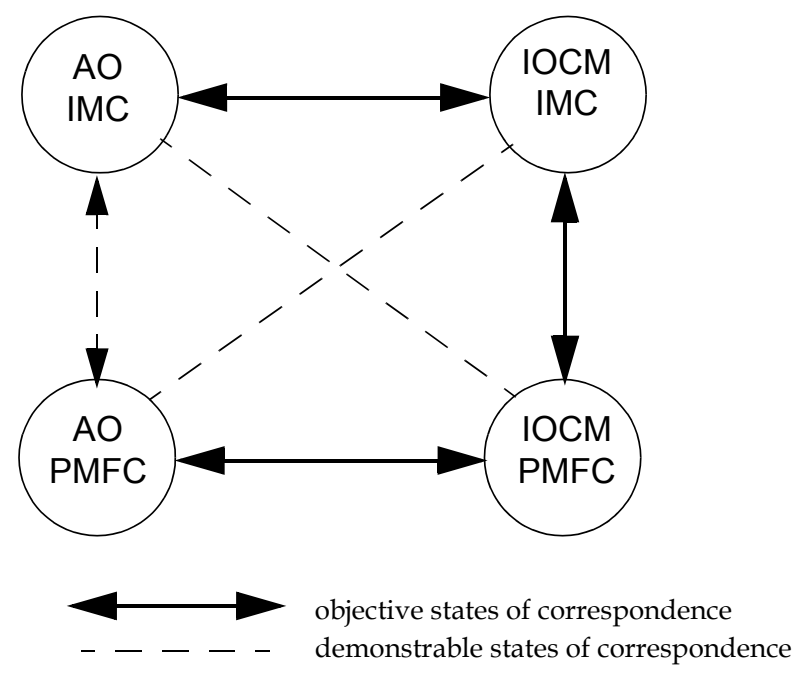

There are obvious pitfalls in this method of determining musical 'meaning'. Just as noone would presume the same morpheme to mean the same thing in two different lan-

7. 'Musiken | kan inte bortförklaras. | Det går inte ens att säga emot, | annat än | med helt ny musik.' 
guages (for instance, French and English [wi:] as 'oui' and 'we' respectively, not to mention 'wee' and 'Wii'), so it would be absurd to presume that, say, the identical $B b 13$ chords in Example 1 will 'mean' the same thing. $\{50\}$

Example 1. Chord of the thirteenth: [a] euroclassical Romantic idiom; [b] bebop



To overcome such difficulties, IOCM should be restricted to musical genres, functions and styles relevant to the AO. Thus, in dealing with punk rock, IOCM would be need to be confined to pop and rock from the sixties and after, whereas the IOCM used in connection with middle-of-the-road pop, film music, etc. can be far larger, due to the eclectic nature of such musics and the heterogeneity of their audiences.

The same kind of confusion might also result in describing What Shall We Do With The Drunken Sailor as sad and 'He Was Despised' from Händel's Messiah as happy, just because minor is supposed to be sad and major happy, as though these particularities of euroclassical tonality were more important than others or universally applicable.

Having extracted the various IMCs of the AO (thirteen main musemes for Kojak, eleven for Fernando), their connotative meaning in verbal form should be corroborated or falsified. Since it is impossible to construct psychological test models isolating the effects $\{51\}$ of one museme in any listening situation, it is suggested that hypotheses of musematic 'meaning' be tested by means of a technique well known from such practices as 'majoring', 'minoring', 'jazzing up' and 'rocking up' and applied by Bengtsson (1973: 221 , ff.) to illustrate theories of musical processes. This technique is called commutation and is best explained by example.

Example 2. Swedish national anthem: first melodic phrase

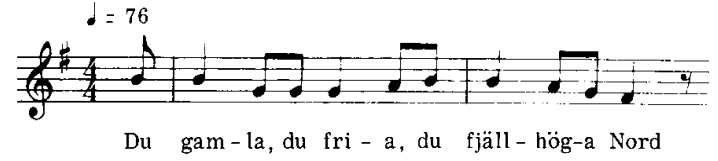

The Swedish national anthem (Du gamla, du fria, Example 2), together with most patriotic songs and hymns (whatever their musical origins ${ }^{8}$ ), can be assumed to be of a traditionally solemn and positively dignified yet confident character. Furthermore, it can be assumed that there is considerable musematic similarity between many national anthems. To test these assumptions, you can alter the various parameters of musical expression one by one, in order to pinpoint what part of the music actually carries the solemn-dignified-confident affect. Using the first melodic phrase (Ex. 2) as a starting point, commutation can falsify the theory that (Example 3a, p. 12) the melodic contour, (3b) the melodic relationship of the initial upbeat-downbeat ${ }^{9}$ and (Ex. 3c) the key and the intervallic relationship of the melody to the tonic are instrumental in the transmis-

8. The Swedish national anthem took its tune from an old folk song with 'naughty' lyrics.

9. This seems to contradict Maróthy (1974: 224-7, 241, ff.). The initial interval (the initium 'intonation' of plainchant, for example) should not be confused with Asafyev's various usages of the word 'intonation'. Asaf' yev calls this type of initial interval voodniy ton (= introductory tone). 
sion of the assumed 'meaning'. In all three cases (Ex. 3a, b, c) the original melody has been changed. The radically altered commutation shown in Example 3a bears nonetheless a striking resemblance to the Marseillaise and could have been made to sound like The Stars and Stripes for Ever, God Save the Queen or the Internationale.

Example 3. Swedish national anthem (first melodic phrase): seven commutations

(a) altered melodic contour

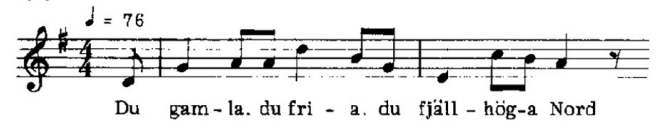

(c) altered key

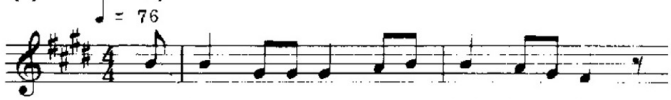

Du gam - la, du fri - a. du fjäll-hög-a Nord

(e) altered tempo

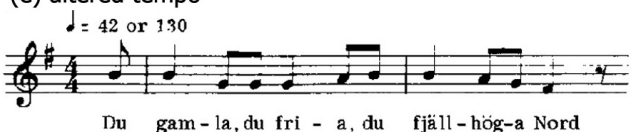

Du gam-la, du fri - a, du fjäll-hòg-a Nord

(g) altered metre

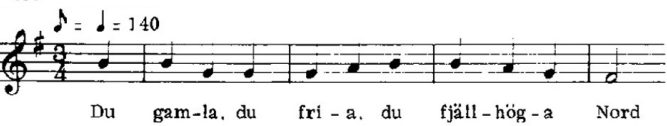

(b) altered upbeat

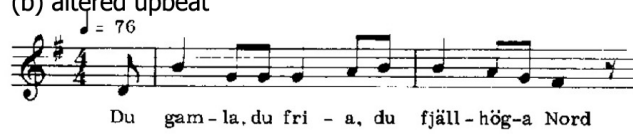

(d) altered phrasing

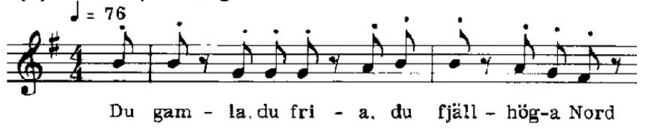

(f) altered lyrics

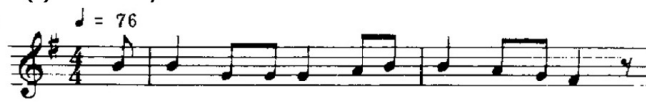

On route six-ty six I'll be get - ting mykicks

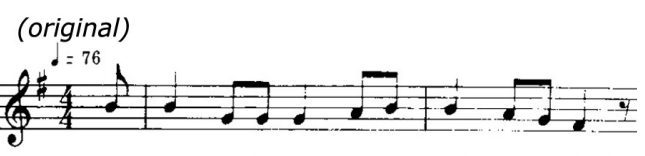

Du gam-la, du fri - a, du fjäll-hög-a Nord

The second commutation (Ex. 3b) shows the first interval as a rising major sixth from fifth to major third, the most characteristic leap in the Soviet national anthem, while the third commutation ( $3 \mathrm{c}$ ) sounds like a mixture of musemes from such labour movement rousers as Bandiera Rossa and Venceremos. It also resembles the 'release' of the Revolutionary Funeral March, Beethoven's setting of Schiller's Ode to Joy and the triumphant chorus from Händel's Judas Maccabeus, not to mention the 'send her victorious' phrase from the UK national anthem. $\{52\}$ It is, however, possible to corroborate assumptions about solemnity and confidence by changing the phrasing (Ex. 3d), the tempo (3e), the lyrics (3f) and the time signature (3g).

By changing the phrasing to staccato, the melody loses much of its dignity, becoming more like a Perez Prado cha-cha-cha (Ex. 3d).10 $\{53\}$ By increasing the pulse rate to an allegro of 130 or more, dignity, solemnity and confidence become a bit rushed; by lowering it to an adagio pulse of forty-two, the confidence turns into something dirge-like (3e). Solemnity seems also to be destroyed by the substitution of 'undignified' lyrics, resulting in something more like blasphemous versions of hymns (3f), and also by retaining the original tempo while stating the tune in triple metre at $140 \mathrm{bpm}$, thus warranting a waltz accompaniment $(3 g)$.

It would also have been possible to alter the dynamics to, say, pianissimo, to give the harmonies the sharpened or flattened added notes characteristic of chords in bebop, to put the melody through a fuzz box, harmoniser or ring modulator, into the minor key or into the Hijaz mode. The original melody could also have been played at an altered pitch on bassoon, piccolo, celesta, synthesiser, hurdy-gurdy, bagpipes, steel guitar or kazoo; it could also have been accompanied by a rock band, crumhorn consort or by offbeat hand claps. A virtually infinite number of commutations can corroborate or falsify correspondences between conclusions about musematic meaning (AO/IMC -

10. See Prado's Patricia, RCA Victor 47-7245, no. 1 on the Hot 100, 1958. See also Tommy Dorsey's Tea for Two ChaCha, Decca 30704, no. $7 \mathrm{n}$ the Hot 100, 1958. 
IOCM/PMFC). However, from the examples presented here it is at least clear that the last four parameters of musical expression (Ex. 3d, e, f, g) are more important determinants of the connotative properties of dignity, solemnity and confidence than the first three (Ex. 3a, b, c), even though change in melodic contour was far easier to detect in notation.

Having established paramusical 'meaning' at the micro level, it's possible to start explaining the ways in which musemes are combined, simultaneously and successively. Unlike the written word, where complexities of lateral or synaesthetic thought can generally only be expressed through a combination of lexical and metaphorical means, music can express such complexities through simultaneously heard sets of musemes. Several separately analysable musemes are combined to form what the listener experiences as an integral sound entity. Such museme stacks can be seen as vertical cross-sections through an imaginary score. 11 Subjectively they seem to have no duration, never exceeding the limits of the extended present; objectively this means they are never longer than the length of a musical phrase, which may be roughly defined as the duration of a normal inhalation plus exhalation (Wellek 1963: 109).12 In popular music, museme stacks can often be found to correspond to the popular notion of 'the sound', one of whose characteristics is a hierarchy of dualisms consisting, firstly, of the main relationship between melody and accompaniment (which may be interpreted as a relationship between figure and ground, individual(s) and environment), and, secondly, subsidiary relationships between bass (plus drums) and other accompanying parts. 13 The $\{54\}$ relative importance of simultaneous musemes and their combined effects, shown as a theoretical model in Figure 4, can be exemplified by the syncritic ${ }^{14}$ paradigm of the first melodic phrase in the Kojak theme (Figure 5, p. 14).

Fig. 4. Syncritic model for analysis of museme stacks

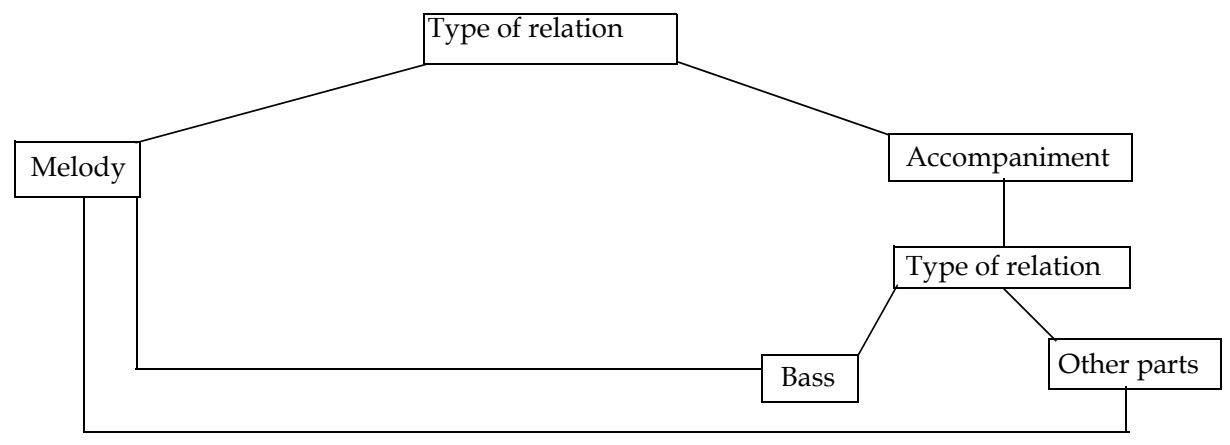

There is no room here to account in detail for stages of musematic analysis leading to the connotative words included in Figure 5 (see Tagg 1979: 102-47). Figure 5 (p. 14) is intended to put a little meat on the bone of this rather dry theoretical presentation.

$\{55\}$ Having established correspondence between, on the one hand, syncritic items of musical expression (musemes and museme stacks) in the $\mathrm{AO}$ and, on the other hand, the PMFCs linked to the IOCM - which leads to conclusions about the relationship between these items as signifiers and their signifieds - it's also necessary to determine the processual meaning of the AO. Thanks to the melody-accompaniment dualism of much popular music (see Mühe 1968: 53, 67; Maróthy 1974: 22; Tagg 1979: 123-124, 142-

11. Museme stacks: see Tagg $(2013: 417,594)$.

12. The extended present lasts no longer than a musical phrase (exhalation), or a few footsteps, or a short gestural pattern, or a few heartbeats. It is a duration experienced as a single unit (Gestalt) in present time, as 'now' rather than as an extended sequence of musical ideas (see Tagg, 2013: 272-273, 588).

13. Melody-accompaniment dualism: see Tagg (2013: 425-484).

14. Syncrisis/syncritic: see Tagg (2013: 417-484, 603). 
147), 13 in which there are rarely more than two parts with melodic material, the remaining voices either executing riffs or sustaining notes or chords, the way to determine the relative syntactic importance of individual musemes along the 'horizontal' time axis is reasonably simple.

Fig. 5. Interpretation of museme stack (syncrisis) in the Kojak theme, bars 5-8

\begin{tabular}{|c|c|c|c|c|}
\hline Melody & $\begin{array}{l}\text { Type of } \\
\text { relation }\end{array}$ & \multicolumn{3}{|c|}{ Accompaniment } \\
\hline \multirow{2}{*}{$\begin{array}{l}\text { a call to action and } \\
\text { attention, strong, indi- } \\
\text { vidual movement, up } \\
\text { and outwards: virile, } \\
\text { energetic and heroic, } \\
\text { leading to undulating } \\
\text { swaying calm and con- } \\
\text { fidence - something } \\
\text { individual, male, mar- } \\
\text { tial and heroic }\end{array}$} & \multirow{2}{*}{$\begin{array}{l}\text { stands out } \\
\text { against, is } \\
\text { heard above, } \\
\text { is stronger } \\
\text { than, is } \\
\text { engaged in } \\
\text { dialogue } \\
\text { with }\end{array}$} & Bass & $\begin{array}{l}\text { Type of } \\
\text { relation }\end{array}$ & Other parts \\
\hline & & $\begin{array}{l}\text { energy, excitement, } \\
\text { desultory unrest: male } \\
\text { aggressiveness, threat } \\
\text { of subcultural environ- } \\
\text { ment in large North } \\
\text { American city }\end{array}$ & $\begin{array}{l}\text { is part } \\
\text { of, rum- } \\
\text { bles } \\
\text { below, } \\
\text { is heard } \\
\text { through }\end{array}$ & $\begin{array}{l}\text { general, constant, bus- } \\
\text { tling activity: agitated, } \\
\text { pleasant, vibrant, } \\
\text { luminous, modern, } \\
\text { urban American: } \\
\text { sometimes jerky, } \\
\text { unresting, exciting }\end{array}$ \\
\hline
\end{tabular}

Fig. 6. 'Deep structure' of melodic phrases $\{55\}$

MP

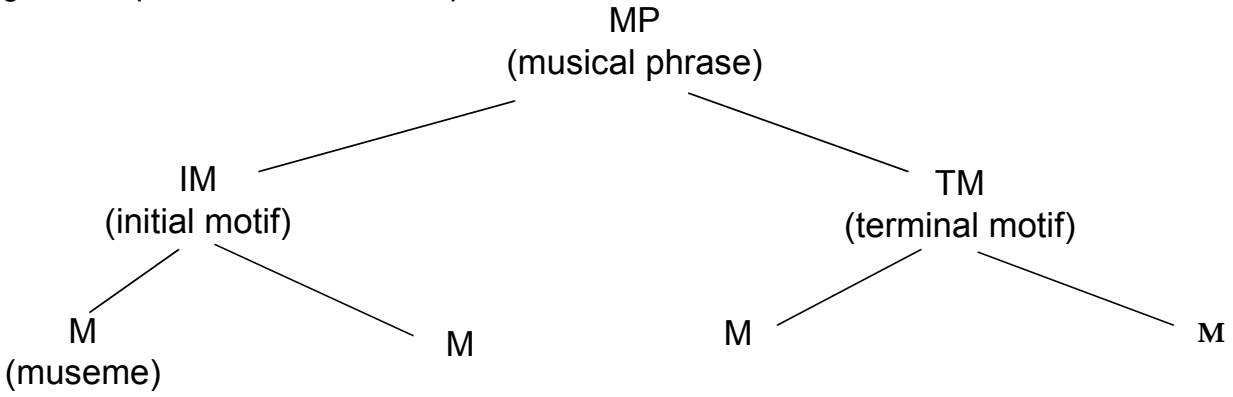

It is in fact possible to construct a model according to which any melodic phrase can be generated in keeping with the transformational norms to which the AO belongs (see Fig. 6). This does not imply that there are hard and fast rules about the way in which melodic phrases are actually generated. The model is a purely theoretical conception, which helps us find out the syntactical meaning of melodic phrases. A generative analysis of the first fully stated melodic phrase from the Kojak theme ('surface structure' at the bottom of Fig. 7) should make this clearer. Starting from the original pitch idea shown at the top of Figure 7, an infinite number of transformations are possible. Two of these, simply using different sequences of musemes, are suggested in Examples 4a and $4 \mathrm{~b}$ (p. 15). Those two examples are melodic nonsense because neither the mere sum, nor the haphazard permutation of musemes can constitute the syntactical meaning of melodic phrases. Instead it is their specific type of contiguity, of overlap-elision according to the 'law of good continuation' (Meyer 1956) and that of 'implication' (Narmour 1977), that give specific meaning to the phrase. This can be seen in a comparison of the original melodic phrase of the Kojak theme (Ex. 4c) and a commutation in which the middle museme, together with its transformation by propulsive double repetition, has been replaced while all other elements have been retained (Ex. 4d). 
Fig. 7. Generative analysis of melodic line in first full melodic phrase of the Kojak theme $\{56-57\}$

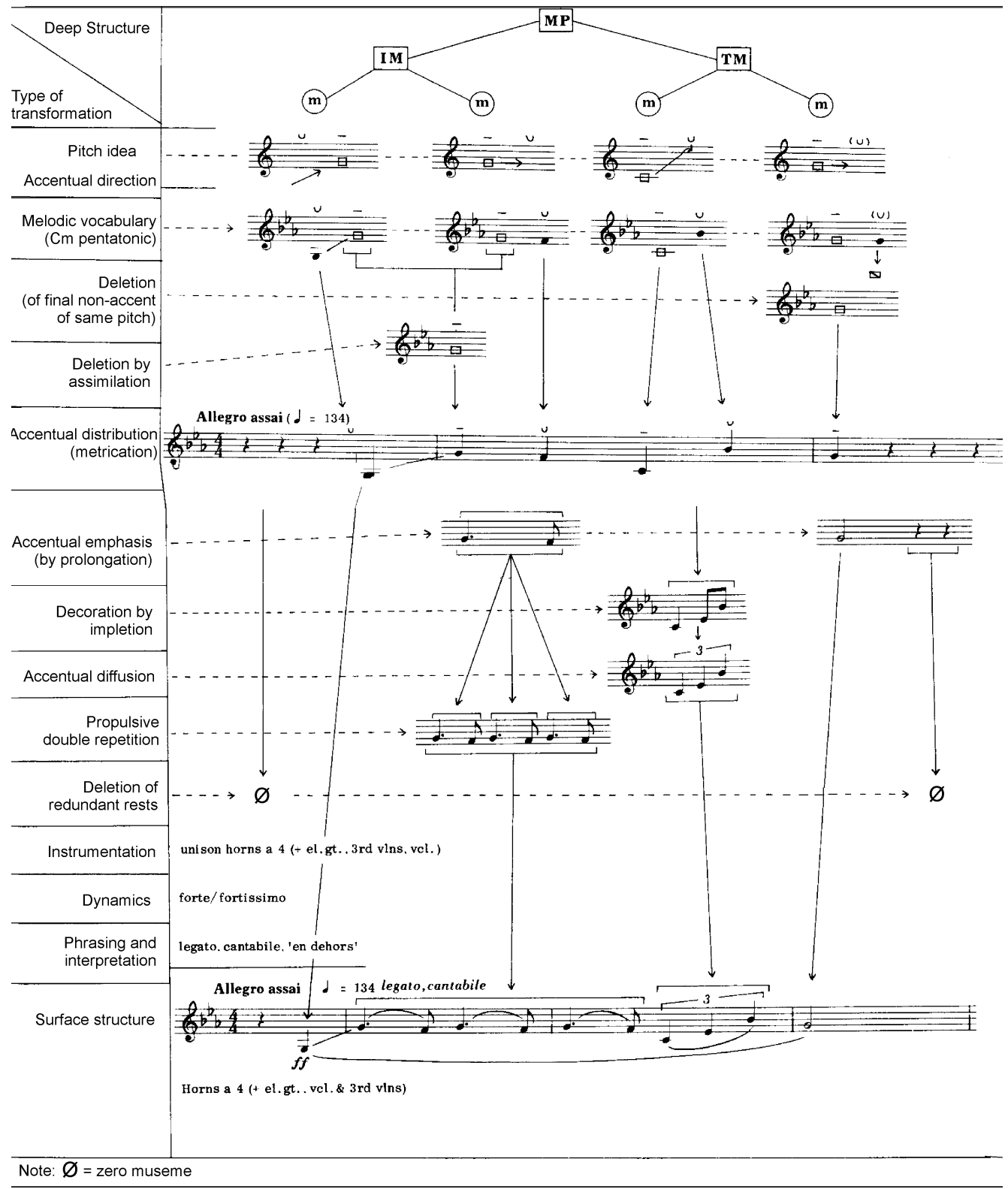

Example 4. Kojak theme, melodic phrase 1: four syntactical commutations $\{58\}$

(a)


(b)

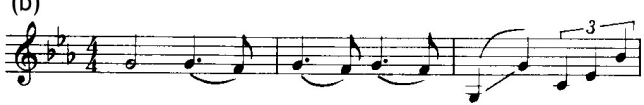

(d) bar 1

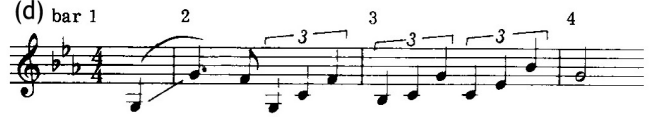

In this way it is possible to distinguish between the syntax of the original version and that of the commutation. The differences can be verbalised as follows. Example 4c: [bar 1] a strong, virile call to attention and action upwards and outwards to [bar 2] something that undulates, sways calm and confident, gaining momentum to lead into [bars 3-4] something strong, broad, individual, male, martial, heroic and definite. Example 
4d: [bar 1] a strong, virile call to attention and action upwards and outwards [bar 2] redescends smoothly to [bar 3] something strong, broad, individual, male, martial and heroic which grows in height and intensity, driving forward to [bar 4] a confident point of rest. In short: although these two melodic phrases contain the same musical material, the order in which the material is presented and the way in which its constituent parts are joined are both instrumental in determining difference of affect and effect.

Climbing further up the structural hierarchy from the microcosm of musemes, through melodic phrases, we arrive at the point where larger patterns of musical process (PMP) can be examined. This area can be regarded as the happy hunting ground of formalist musicology with its conceptual apparatus for discussing thematic germination, mutation and development. 15 However, as Chester (1970) has suggested, there are clear differences between the 'extensional' type of musical discourse to be found in the heyday of the sonata $\{59\}$ form and the 'intensional' blocks through which much popular music is structured in a much more immediate way. ${ }^{16}$ Of course, none of this means that patterns of musical process are necessarily a simple matter in popular music analysis (see Wicke 1978, Tagg 1979). Although block shifts (simultaneous changes in several parameters of musical expression) are reasonably clear in joins between verse and refrain, $\mathrm{A}$ and $B$ sections, etc., the total meaning of straightforward patterns of reiteration and recapitulation can often be more than their deceptive simplicity suggests. (For discussion of some of the processes involved, see Tagg 1979: 217-29).17 The situation becomes even more complex when there is incongruence between musical processes and paramusical processes (PMP: visual images or words, for instance) in the same AO. Only a in-depth analysis of simultaneity, of staggering or incongruence of change and return in both musical and paramusical processes within the AO can actually reveal the true nature of the musical discourse. The sort of problem involved here is probably best explained by an example.

In Abba's Fernando, 18 patterns of musical and paramusical process seem reasonably clear at first sight. The song has two parts: instrumental plus verse (V) and refrain (R). The order of events is V V R V R R. Using musematic analysis, the verse can interpreted as a postcard picture of a young European woman alone against a backcloth of a plateau in the high Andes. Periodicity, vocal delivery, lack of bass and drums, and other aspects of musical structure tell us that she is sincere, worried, involved in a long-agoand-far-away environment. The words of the verse underline this mood: she has taken part, together with her 'Fernando', in a vaguely mentioned freedom fight. The music of the refrain can be said to represent here-and-now in pleasant, modern, comfortable, leisurely surroundings; the young European woman is pleasantly nostalgic. The words are congruently nostalgic and devoid of the concrete references (guns, bugle calls, Rio Grande, etc.) mentioned in the verse. Everything in the analysis seems relatively simple so far, and judging from the words of the chorus, this could be quite a 'progressive' song.

'There was something in the air that night, the stars were bright, Fernando,

They were shining there for you and me, for liberty, Fernando;

Though we never thought that we could lose, there's no regrets:

If I had to do the same again, I would, my friend, Fernando.

15. i.e. episodic form or diataxis as opposed to form contained within the extended present - syncrisis. For explanations of these terms, see Tagg (2013: 383-385; 586, 588, 603).

16. For a more detailed discussion of extensional and intensional structures, see Chambers 1982:29-30.

17. See also the diataxis chapter in Music's Meanings (Tagg, 2013: 383-416).

18. Epic EPM 4036, no. 1 in the UK, 1976. Also on LP Abba's Greatest Hits Epic EPC 69128, 51 weeks on UK LP charts. As a single in the USA (Atlantic 45-3346) sixteen weeks in the 'Hot 100'. A short analysis of this tune was already published as Tagg 1981a, this version being radically expanded and rewritten as Tagg 1991. 
Example 5. Abba: Fernando (1975): tritone museme $(x)$ at start of refrain (over $E^{7}$ )



Example 6. IOCM for tritone museme $(x)$ in example $5\{60\}$

a. Bach, Matthäus Passion (1729), 'Ich will bei meinem Jesu wachten'

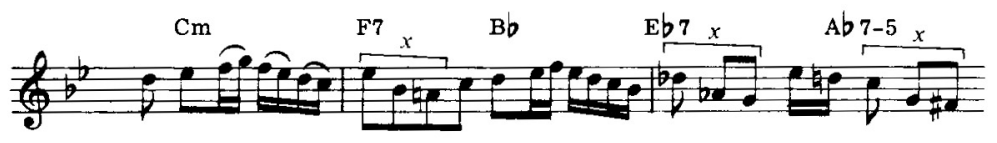

b. Gluck, Orfeo e Euridice (1774), 'Che faró senza Euridice?'

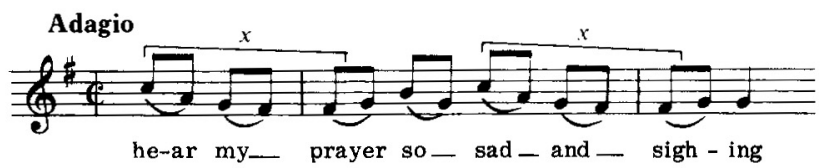

c. The Righteous Brothers, 'You've Lost That Loving Feeling', Philles 124



$\{60\}$ The only trouble is that the musical element corresponding to this nostalgia and longing to return to the exotic environment (Ex. 5) is a highly ambiguous museme, for not only is its falling tritone (marked $x$ ) a stereotype of 'longing' (for IOCM see Ex. 6a, $b, c)$ but also a typical precadential sign of the imminent relaxation of tension (see Examples 7-8). An in-depth analysis of the patterns of musical process in Fernando reveals that when the ambiguous museme occurs at the start of the refrain it has a longing character (Ex. 5), since it cannot be precadential when it not only initiates the phrase but also the whole section.

However, when it recurs at the end of the refrain (Ex. 9, p. 18) it has more in common with the cadential function of $x$ in Examples 7 and 8, where it coincides with a V7 chord in a $V \rightarrow I$ cadence. Admittedly, it still starts the melodic phrase but at the same time it announces imminent relaxation of tension $(V \rightarrow I)$ and therefore no real longing. This sense of finality is reinforced because it occurs towards the end of a longer but equally well-entrenched musical process, that of a familiar VI-II-V-I circle-of-fifths finish (F\#7B7-E7-A in Ex. 9). This means that, whereas the words say 'If I had to go back and fight for freedom in Latin America, I would", the music expresses the attitude "I may be longing for something here at home but I'm really quite content with things as they are'. $\{61\}$

Example 7. Njurling \& Dahlqvist (1924): Skepp som mötas i natten cadential 8-\#7-4 IOCM19

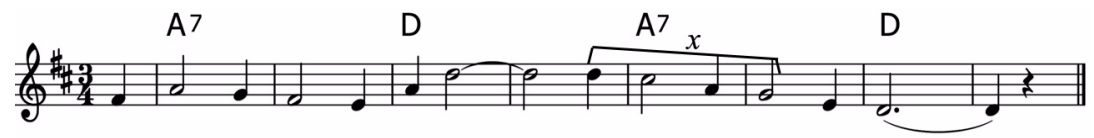

Example 8. Alf Prøysen: Lilla vackra Anna —partly cadential $\sharp 7-4$ tritone IOCM $^{20}$

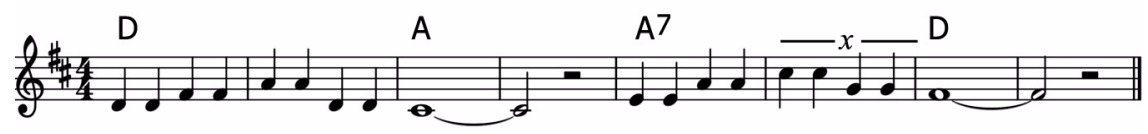

19. a.k.a. 'Axel Öman'; in Svensk schlager, ed. F G Sundelöf (Stockholm, 1968).

20. In Visesangboka, ed. O Leren \& L Damstad (Oslo, 1971). 
Example 9. Abba: Fernando (1975) -8- \#7-4 tritone as cadential

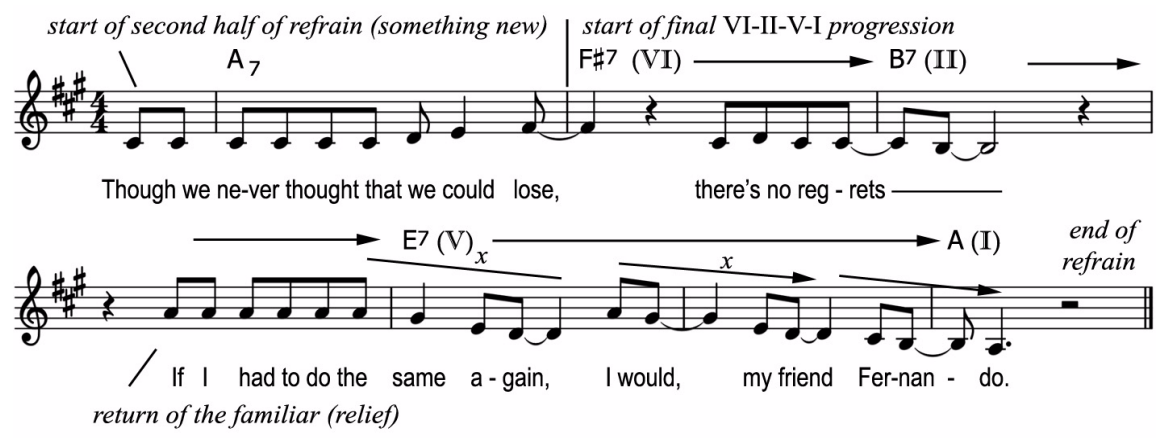

Difficulties in interpreting patterns of musical process can also be found further up the processual (diatactical) hierarchy in the same song. Ostensibly, three main processes are to be found. The first and third move from the sincere-worrying-and-involvementabout-fighting-for-freedom-in-the-sierras sphere to the world of here-and-now-athome in pleasant, comfortable surroundings, reminiscing with relief (that is $\mathrm{V} \rightarrow \mathrm{R}$, from verse into refrain); the second process moves in the opposite direction $(R \rightarrow V)$. However, not only are there more shifts from verse to refrain than vice versa, there is also an overall process from 'more "Andes" (verse) and less "soft disco"' (refrain) - the first half of the song - to "less "Andes" and more "soft disco"' — the second half. A processual commutation reversing this order of events leads to a totally different statement of emotional involvement in musical terms. ${ }^{21}$

At this point in the analytical model we are poised on the brink of 'ideological critique', the next and final step in the methodological paradigm presented earlier (see Fig. 2). $\{62\}$

\section{Ideological critique}

This part of the study is strictly speaking outside the jurisdiction of the type of 'textual analysis' sketched above. However, it seems important, if only in passing and by way of summary, to pose a few questions arising out of the sort of musematic analysis illustrated there. These questions also put the analytical model presented so far into a broader perspective.

The results of the detailed musematic analyses of both Kojak and Fernando (Tagg 1979, 1981a) showed that this mainstream popular music was able to carry messages which, at preconscious and connotative levels of thought, were able to relate types of personality, environments and events to emotional attitudes, implicit evaluations and patterns of response. In the case of Kojak, for example, the music was found to reinforce a basically monocentric view of the world and to reinforce the fallacy that the negative experience of a hostile urban environment can be overcome solely by means of an individualist attitude of strength and go-it-alone heroism. In Fernando, a similar sort of monocentrism prevails, but the threat and worry epitomised by oppression, hunger and rebellion under neo-colonialism are warded off by the adoption of a tourist attitude (most strikingly expressed in the spatial panning, which has 'ethnic' quena flutes in the stereo wings and the West European vocalist up centre front - a commutation reversing these positions could have been interesting!) and by nostalgic reminiscences heard against a familiar 'home' accompaniment of 'soft disco' (these elements gaining a repressive, Angst-dispelling upper hand).

21. These arguments about the processual meaning of Fernando are explained in more detail in Fernando the Flute (Tagg, 2000: 67-77) and in the diataxis chapter of Music's Meanings (Tagg, 2013: 386-394). 
Obvious questions arising from such results are of the following type. How do 'emitter' and 'receiver' relate to the attitudes and implicit ideologies which seem to be encoded in the analysed 'channel'? Starting with the 'emitter' we might ask how the conception and composition of these musically encoded attitudes are influenced by the circulation of capital in the popular culture industry. Does this connect with the demand for quick turnover and the creation of 'product' capable of eliciting immediate audience reaction leading to such turnover? If so, how aware is the 'emitter' of these pressures? Is there any conscious or unconscious self-censorship at this stage? It seems probable, for example, that the production of much film music, including titles and signature tunes is influenced by a need to follow well-entrenched stereotypes of musical code, in terms of both musematic structure and the implicit attitudes conveyed by such structures when connected in a stereotypical fashion to extramusical phenomena (see Tagg 1980). Can such tendencies really be seen as a sort of evil conspiracy and as the reflection of a conscious ideological position on the part of the 'emitter'? Is it not more likely that they should be attributed to the objective social and cultural position of the 'emitter' in relation to the music business, to the 'receiver' and to society in general? $\{63\}$

Turning to the receiving end of the communication process, we might ask how the musical statement of implicit attitudes prevalent in society at large affects those listening to such culturally eclectic and heterogeneously distributed types of music as title tunes and middle-of-the-road pop. Are the attitudes and behaviour patterns implied in such music as Kojak and Fernando actually capable of reinforcing the attitudes and behaviour patterns implied by prevailing social tendencies of monocentrism, privatisation and idealist individualism; or are these messages merely received at a distance as entertaining reflections of an outdated mode of relating to current reality? Obviously, reception of such 'consensus music' (Hamm 1981) will vary considerably between different cultures, subcultures, classes and groups. Thus, whereas parts of the 'fourth audience' (ibid.) may well be able to identify with the affective attitudes towards love, family, society and nature (on 'nature' in music, see Rebscher 1976, Rösing 1977, Tagg 1982) presented in such TV music as Kojak or in such middle-of-the-road pop as Fernando, it is clear that many will be unable to identify. This raises yet another question: how does the latter type of listener relate to prevailing ideologies and attitudes both in music and in society at large?

\section{Analysing subcultural music codes in industrialised society}

The way in which 'counter-cultures' and subcultures express their own stand, profile and group identity in paramusical terms has been documented in numerous studies (see the work of the Centre for Contemporary Studies at the University of Birmingham). However, the musical coding of such identities is an underdeveloped field of study. There are admittedly numerous accounts of trends within Afro-American music, but few of these deal with the actual musical code of the counter-culture or subculture in question. This could be because no real theory yet exists which explains how the prevailing attitudes, patterns of behaviour and ideology of late capitalism are encoded in the musical mainstream of popular musics such as signature tunes, Muzak, advertising music, middle-of-the-road pop and rock, etc. In fact, it appears that the study of popular music has, with very few exceptions (such as Mühe 1968, Czerny and Hoffmann 1968, Hamm 1979, 1981, 1982, Gravesen 1980, Helms 1981) shown a remarkable bias towards tributaries or offshoots, while strangely ignoring the mainstream. $\{64\}$

It is difficult to refrain from speculating about possible reasons for such bias. Perhaps there is a tendency among intellectual musicians or musically interested academics to be critical towards the stereotypical encoding of mainstream attitudes and ideas in our society. If so, it seems natural that such researchers will be more likely to identify with musics 'contradicting' the mainstream and thus be motivated to explain the 'contra- 
dicting' position they themselves assume rather than the 'contradicted' which they leave shrouded in mystery, an inaccessible, unidentified enemy. But it is hard to understand how the popular music researcher will ever be able to explain his/her 'music in opposition' (or even how 'music in opposition' will be able to develop a valid strategy) if the ideologies encoded in the musical mainstream are not to be touched.

This matter was put tersely by William Brooks at Keele University during a seminar on Afro-American music in 1978. He expressed the opinion that it is no use trying to find out why Chuck Berry is so great if you do not know why Perry Como is so successful. How, one wonders, can the true values of Sonnevi's 'contradicting musical exception' (see p. 10 above) be realised if the face of the 'prevailing musical norm' is never unmasked.

Analytical methods developed along the lines of the model presented here may perhaps contribute to this unmasking operation. Whether or not they might then be applicable to subcultural musical codes, such as Tyneside workers' song, reggae or punk, is another question. The problems would be numerous and can be generalised as follows. (1) Detailed genre definitions will need to be made (for a possible method, see Fabbri 1982 and his contribution to this volume). (2) Acceptable style criteria will need to be established on the basis of the musical traits accepted and rejected by musicians and listeners belonging to the subculture. (3) The subcultural musical code will probably need to be considered as a potential carrier of particular socialised relationships between members of the musical subculture and the musical mainstream (this presumably reflecting comparable social relationships) rather than as carrier of quasi-universalised attitudes and relationships towards an apparently wider and vaguer set of general, individualised experience (see Wicke and Mayer 1982). Such considerations seem to imply that the model presented in this article will require some alteration before being applied to the analysis of subcultural popular musics. 22

\section{Popular music analysis - its uses}

As usual in theoretical presentations like this, more questions seem to get asked than answers given. However, results from the in-depth studies of title music and middleof-the-road pop carried out so far $\{65\}$ suggest that the sort of hermeneutic-semiotic analysis presented here can provide some insight and act as a basis for understanding 'what is being communicated' and 'how'.

Now, it is true that my analytical model has been distilled from detailed, almost microscopic studies of individual pieces of popular music. Such microscopic investigation was carried out in order to test thoroughly the viability of certain hypotheses and intuitive analytical practices. It resulted in pieces of writing (400 pages for a one-minute title theme, 160 pages for four minutes of pop!) far too cumbersome to be used as models in normal teaching situations. However, this does not mean that the basic techniques problematised and tested in this way are unusable in normal circumstances, not least because the need to test and develop these models evolved from the practical problems of teaching popular music history at a teachers' training college, where there was certainly no time to spend more than a few minutes talking about single pieces of music. ${ }^{23}$

The methods of interobjective comparison, of establishing correspondence between the IOCM and its PMFCs and then between the musical code of the analysis object (AO/ IMC) and the paramusical fields of connotation connected with the interobjective com-

22. Some of those alterations are mentioned in the Preface to this article and in footnotes 1 and 2 (p. 1). They are also accounted for at numerous points in Music's Meanings (Tagg, 2013).

23. See 'The Göteborg Connection: lessons in the history and politics of popular music education and research' (Tagg, 1997). 
parison material (IOCM/PMFC) (see Fig. 3, p. 10) can be carried out by anyone willing to exercise their synaesthetic brain, lateral thinking and intellect. Any musician can carry out simple commutation and, with basic audio software 24 and a reasonable ear, anyone can even manage to reassemble a processual commutation. Anyone with a bit of imagination can sing bits of tune in the wrong order, or substitute new continuations, and thereby discover what actually makes the music say what it says.

In other words the analysis of popular music should in no way be considered a job reserved for 'experts' (although I will admit that describing its mechanisms may require some specialist knowledge). The sort of analytic model presented here should rather be seen as an effort to underpin intellectually that form of affective and implicit human communication which occupies parts of the average Westerner's brain during one quarter of his/her waking life - music. (Can any other form of communication rival this, quantitatively?) Analysing popular music should as be seen as something which counteracts 'split brain' tendencies, resists the sort of mental apartheid advocated by the newspapers quoted at the start of this article and breaks the schizophrenic taboos prohibiting contact between verbal and nonverbal, explicit and implicit, public and private, collective and individual, work and leisure. Analysing popular music takes the 'fun' seriously and is itself both a serious business and a lot of fun. $\{66\}$

\section{References}

ASAFYEV, Boris V (1976). Die musikalische Form als Prozess. Berlin: Verlag neue Musik.

BENGTSSON, Ingmar (1973). Musikvetenskap - en översikt. Lund: Esselte.

BERNSTEIN, Leonard (1976). The Unanswered Question. Cambridge: Harvard University Press.

BRADLEY, Dick. 1980. 'The cultural study of music'. Stencilled paper from the Centre for Contemporary Cultural Studies, no. 61. Birmingham.

CHAPPle, Steve, and GAROFALO Reebee (1977). Rock-'n'-roll Is Here To Pay. Chicago: Nelson Hall.

CHAMBERS, Iain (1982). 'Some critical tracks'. Popular Music, 2: 19-36.

CHESTER, Andrew (1970). For A Rock Aesthetic. New Left Review, 59: 82-86.

COHN, Nik (1970). Awopbopaloobopalopbamboom. St Albans: Paladin.

CZERnY, P and HoffMAN, H P. Der Schlager. Berlin: VEB Lied der Zeit.

FABBRI, Franco. 'A Theory of Genres: two applications in Italian popular song'. Popular Music Perspectives (ed. P Tagg and D Horn): 52-81. Göteborg, Exeter: IASPM.

Fonogrammen i kulturpolitiken (1979). Rapport från Kulturrådet, 1979:1. Stockholm: Liber.

FRANCÈS, Robert (1958). La perception de la musique. Paris: J Vrin.

FRITH, Simon (1978). The Sociology of Rock. London: Constable.

GRAVESEN, Finn (1980) '"Party-musik - introduktion til en genre'. Nordisk musik och musikvetenskap under 70-talet (ed. A Carlsson and J Ling): 261-276. Göteborg: Skrifter från Musikvetenskapliga institutionen.

HAMM, Charles (1979). Yesterdays - Popular Song in America. New York: Norton.

- (1981) 'The fourth audience'. Popular Music, 1: 123-142.

- (1982) 'Popularity in music - aesthetics and procedure'. Popular Music Perspectives (ed. P Tagg and D Horn). Göteborg and Exeter: IASPM.

HeLMS, S (1981). Musik in der Werbung. Wiesbaden: Breitkopf und Härtel.

KARBUŠICKY, Vladimir (1973). Das ‘Verstehen der Musik' in der soziologischen-ästhetischen Empirie'. Musik und Verstehen - Aufsätze zur semiotischen Theorie, Ästhetik und Soziologie der musikalischen Rezeption (ed. H P Reinicke and P Faltin (eds): 121-147. Köln: Volk/Gerig.

KARSHNER, Roger (1971). The Music Machine. Los Angeles: Nash.

24. 'Basic audio software' (2015) has replaced 'a tape recorder, tape and a razor blade' (1982). 
KEILER, Allan (1978). Bernstein's The Unanswered Question and The Problem of Musical Competence. Musical Quarterly: 198-222.

LERDAHL, F and JACKENDOFF, R (1977). Toward a Formal Theory of Tonal Music. Journal of Music Theory, 1977/1: 111-171.

LING, Jan (1978a). Assafjevs intonationsteori: ett försök till analys. Stencil, Göteborg: Musikvetenskapliga institutionen, Göteborgs universitet.

- (1978b). Hjort Anders' 12th Day March. Antropologiska Studier, 25/26: 122-139.

MARótHY, János (1974). Music and The Bourgeois, Music and The Proletarian. Budapest: Akadémiai Kiadó.

MELLERS, Wilfrid (1973). Twilight of the Gods. London: Faber.

MELZER, R (1970). The Aesthetics of Rock. New York: Something Else Press.

MEYER, L B (1956). Emotion and Meaning in Music. Chicago: Chicago University Press.

MÜHE, Hansjörg (1968). Zur Intonation des deutschen Schlagers: Untersuchungen an in der DDR gespielten Evergreens. (Unpublished doctoral dissertation). Leipzig: Karl-Marx-Universität.

NARMOUR, E (1977). Beyond Schenkerism - The Need for Alternatives in Music Analysis. Chicago University Press. $\{67\}$

NATTIEZ, Jean-Jacques (1974). Sur la relation entre sociologie et sémiologie musicales. International Review of the Aesthetics and Sociology of Music 5/1: 61-75.

REBSCHER, Georg (1976). Natur in der Musik. Wiesbaden: Breitkopf und Härtel.

RIETHMÜLLER, Albrecht (1976). Die Musik als Abbild der Realität: zur dialektischen Wiederspieglungstheorie in der Ästhetik. Wiesbaden: Beihefte zum Archiv für Musikwissenschaft, 15.

RÖSING, H (1977). Musikalische Stilisierung akustischer Vorbilder in der Tonmalerei. München \& Salzburg: Katzbichler.

- (1981). Die Bedeutung musikalischer Ausdrucksmodelle für das Musikverstndnis. Zeitschrift für Muskpädagogik, 16: 158-264.

SCHAFER, R Murray (1974). The New Soundscape. Wien: Universal Edition.

- (1977). The Tuning of The World. Bancroft: Arcana.

SCHULER, Manfred (1978). Rockmusik und Kunstmusik der Vergangenheit. Archiv für Musikwissenschaft, 35: 135-150.

SEEGER, Charles (1960). On the moods of a musical logic. Journal of the American Musicological Society, 13: 224-261.

SHEPHERD, John (1977). 'Media, social process and music', 'The "meaning" of music' and 'The musical coding of ideologies'. Whose Music? A Sociology of Musical Languages (ed. J Shepherd et al.). London: Latimer.

STOÏANOVA, Ivanka (1978). Geste - texte - musique. Paris: Union Générale d'Éditions.

TAGG, Philip (1979). Kojak - 50 Seconds of Television Music. Göteborg: Skrifter från Musikvetenskapliga institutionen, 2; revised and updated version (2000), see tagg.org/mmmsp/kojak.html.

- (ed. 1980). Film Music, Mood Music and Popular Music Research. Göteborg: Stencilled Papers from the Gothenburg University Musicology Department, 8002; tagg.org/articles/xpdfs/ Intvws80.pdf.

- (1981). 'Fernando the Flute' - Analysis of affect in an Abba number. Stencilled Papers from the Göteborg University Musicology Department, 8106 (radically revised and expanded as Tagg 1991); online version (2000) at tagg.org/mmmsp/fernando.html.

- (1982). 'Nature as a Musical Mood Category'. Göteborg: Stencilled Papers from the Gothenburg University Musicology Department, 8206; online at tagg.org/articles/xpdfs/nature.pdf.

- (1991). Fernando the Flute. Liverpool: Institute of Popular Music, Liverpool University; improved online version (2000) at tagg.org/mmmsp/fernando.html.

- (1997). 'The Göteborg Connection: lessons in the history and politics of popular music education and research'. Popular Music 17/2: 219-242 (1998); tagg.org/articles/xpdfs/gbgcnnct.pdf.

- (2013). Music's Meanings: a modern musicology for non-musos. New York \& Huddersfield: Mass Media Music Scholars' Press; see tagg.org/mmmsp/NonMusolnfo.htm. 
TARASTI, Eero (1978). Myth and Music. Den Haag: Mouton.

VARIS, Tapio (1975). The Impact of Transnational Corporations of Communication. Tampere: Tampere Peace Research Institute Reports no. 10.

WEDIN, Lage (1972). Multidimensional Scaling of Emotional Expression in Music. Svensk Tidskrift för Musikforskning, 54: 115- 131.

WELLEK, A (1963). Musikpsychologie und Musikästhetik. Frankfurt-am-Main.

WICKE, Peter (1978). Licht in das Dunkel - Popmusik in der Analyse. Beiträge zur Musikwissenschaft, 1978/1: 3-15. Berlin: Verlag neue Musik.

WICKE, Peter and MAYER, Günther (1982). 'Rock music - some progressive aspects of capitalist mass culture'. Popular Music Perspectives (ed. P Tagg and D Horn). Göteborg and Exeter: IASPM.

ZAK, Vladimir (1979). O melodik'e massovoi pesni (On the melodies of popular song). Moskva: Vsesoyuznoye izdatel'stvo Sovietskii Kompozitor.

ZOLTAI, Dénes (1970). Ethos und Affekt, trans. by B Weingarten. Budapest: Akadémiai Kiadó. 